\title{
Predictors of Youth Voluntary Participation in Urban Agriculture Programme in Malaysia: A Review
}

\author{
Neda Tiraieyari ${ }^{1} \&$ Azimi Hamzah ${ }^{1}$ \\ ${ }^{1}$ Putra Info-Port, Institute for Social Science Studies (IPSAS), Universiti Putra Malaysia, UPM 43400, Malaysia \\ Correspondence: Neda Tiraieyari, Institute for Social Science Studies, Universiti Putra Malaysia, UPM 43400, \\ Malaysia. Tel: 60-012-6059-713; Fax: 89471865. E-mail: ntiraie@yahoo.com
}

Received: July 23, $2014 \quad$ Accepted: August 4, $2014 \quad$ Online Published: November 18, 2014

http://dx.doi.org/10.5539/mas.v9n1p1 URL: http://dx.doi.org/10.5539/mas.v9n1p1

\begin{abstract}
Urban agriculture (UA) has drawn the attention of Malaysian policy makers. University Putra Malaysia (UPM) has taken the lead in introducing programmes to urban residents. The university's strategy is to train student volunteers to play the role of change agents serving urban residents to implement the programme. UPM programme planners need to build a large population of long-term students who voluntarily participate in the programme. Hence the university, specifically the faculty of agriculture, is meeting the challenge to produce candidates prepared with the knowledge, skills, and disposition to participate voluntarily in the UA programme. This paper reviews the existing literature on factors to predict voluntary participation among young students. The authors propose a conceptual model for programme developers to promote youth participation in a voluntary programme. Research is recommended to predict factors influencing UPM students' voluntary participation in the UA programme. Further research is also recommended to explore how programme planners can overcome potential barriers to students' participation in the programme. These investigations could help stakeholders design a programme that appeals to more students and urban residents.
\end{abstract}

Keywords: college students, urban agriculture, urban residents, voluntary participation, youth

\section{Introduction}

UA is defined as growing and distributing fruits, vegetables, herbs, and animal products through cultivation in cities and suburbs (Bailkey \& Nasr, 2000). The connection between UA and food security has been acknowledged for many years (Atkinson, 1994; Gutman, 1987; Sanyal, 1987; FAO, 2010). Studies have shown that UA contributes to enhanced urban food security, recycling of nutrients, community development, opportunities for leadership development, job opportunities that generate income, a social safety net for poor populations and the maintenance of green spaces (Stewart et al., 2013; Brown \& Jameton, 2000).

In Malaysia, rapid urban expansion is driven by economic growth and migration from rural to urban areas. Large numbers of youths are immigrating to the cities, resulting in a rural youth population of only about $10 \%$ to $15 \%$ (Duflot, 2012). Aged farmer populations in rural areas, the need for greater food security and the importance of agriculture to the economy have all drawn the attention of Malaysian policy makers towards implementing UA in urban areas.

Recently, the University Putra Malaysia (UPM) has taken the lead in introducing UA programmes to people living in urban areas. UPM has launched UA in an effort to encourage city dwellers to carry out modern farming activities in the limited spaces of their homes as a guaranteed source of food for the nation by 2020. In so doing, UPM aims to become a centre for guaranteeing food and maintenance of green spaces for urban areas.

In order to make this plan a reality, extension education will be used as the main service delivery instrument. According to Swanson (1997), extension is a form of non-formal education, which enables advisory services to use an educational process to help people in acquiring the knowledge and skills to meet their needs in their own socioeconomic contexts. Therefore, UPM aims to play the role of extension agent in providing technical services on UA to urban residents who lack the necessary knowledge and skills in production, processing, and marketing. UPM's strategy is to encourage university students to train urban residents implementing UA. UPM involves undergraduate students as volunteer extension agents in transferring related knowledge and skills on UA to city residents. Youth voluntary participation contributes to the development of the community and the social and 
psychological development of the young people involved. Hence, UPM programme planners need to build a large population of long-term volunteers in order to train urban residents.

However, prior to encouraging UPM students to participate in the programme it is imperative for programme developers to understand the factors that influence youth voluntary participation. This study aims to aid programme developers and policy makers in identifying the most important factors related to youth participation in a voluntary programme. Results can be used to develop strategies to enhance programme participation. In line with this, the current study aims to address the following research question:

What factors predict youth participation in a voluntary programme?

\section{Literature Review}

\subsection{Antecedents of Voluntarism}

Snyder \& Omoto (2008) define volunteer work as comprising liberally selected and thoughtful helping actions without reward. Verduzco (2010) defined volunteering as unpaid support given to another person who is not a family member. Several variables have been linked to volunteerism. Personality traits are one of the factors that have been ascribed to volunteerism in several studies. According to Omoto, Snyder, \& Hackett (2010) and Wilson (2012) extraverts are more likely to volunteer as they are more likely to belong to voluntary associations and for this reason are more likely to be engaged for volunteer work. People who suffer from social phobia are less likely to participate in a programme as a volunteer (Wilson, 2012).

Scholars have tried to understand why individuals may share common interests for a cause, yet choose not to participate in a programme (Haski-Leventhal \& Cnaan, 2009; Koehler \& Koontz, 2008). Discussion has emerged among volunteerism researchers concerning whether motivation to join and subsequently participate is mostly influenced by cognitive, demographic or social factors (Warburton, Terry, Rosenman, \& Shapiro, 2001). Relevant literatures are mostly uncertain with regard to the effects of demographic factors, including income, gender, marital status, education and employment upon volunteer behaviour (Wilson, 2012). Some research on volunteering has found strong, positive correlations between demographic variables and volunteer behaviour across a wide range of behaviours (Smith, 1994; Wilson \& Musick, 1999).

In addition, neither of these studies found correlations between active participation and marital status, education or employment status, whereas Koehler \& Koontz (2008) found a significant correlation between participation and gender, however, Martinez \& McMullin, (2004) did not. Another study conducted by Simpkins, Ripke, Huston, \& Eccles (2005) reported demographic variables as predictor of youth participation in a number of out-of-school programmes. Results showed that there were no differences in participation based on gender and that such programmes appeal to both boys and girls.

Regarding income, Koehler \& Koontz (2008) found no significant association to active participation; while Martinez \& McMullin (2004) found that, active members actually tend to have lower incomes than those who are not active participants. Studies showed that people are considerably more likely to volunteer after a personal appeal (Martinez \& McMullin, 2004; Smith, 1994). In fact, according to Smith (1994) being asked to volunteer has been identified as the strongest predictor of volunteer behaviour, above attitudinal, motivational, or demographic influences.

Regarding race, the influence of race on volunteering and the pattern of association vary from study to study. It depends on the nature of the sample and the measure of volunteerism (Wilson, 2012). Foster-Bey (2008) found that Whites are more likely to volunteer than African Americans regardless of social class, and Hispanics and Asians less likely to volunteer than either group (data from the U.S. Current Population Survey). Multivariate analyses suggest no racial differences to volunteering (Laurence, 2009).

However, a factor such as educational achievement is feasibly the most important quality for voluntary work (Huang, Maassen van den Brink, \& Groot, 2009). This is somewhat related to factors such as highly educated people are involved in more organizations and also they have higher levels of cognitive competence, and higher status jobs (Gesthuizen, Meer, \& Scheepers, 2008; Gesthuizen \& Scheepers, 2010). Brand (2010) indicated that college achievement has a great impact on volunteering among students compared with those who have not completed college.

Another anticipant of volunteerism is being in work. Einolf (2011) reported that part-time workers are more likely to volunteer than full-time workers. Although volunteering is a dedication of a person's time and it is not clear if income would influence it. However, many studies have found that low-income earners volunteer less. It is probably because they belong to fewer voluntary groups. Similarly Pho (2008) has concluded that low- to medium earners are less likely to volunteer, while Lee \& Brudney (2009) report that the effect of income is not 
linear.

After school activities, especially in the United States, are an organizational basis for all kinds of extracurricular activities. Students and young adults are more likely to volunteer if they have belonged to many clubs and associations. Findings showed that young adults volunteer more in activities if they had participated as high school students in extracurricular activity that demanded considerable time and commitment (McFarland \& Thomas, 2006). Mandatory volunteering is another influential factor. Most studies have concluded that mandatory programmes improve attitudes towards volunteer work and would encourage later volunteering (Bowman, Brandenberger, Lapsley, Hill, \& Quaranto, 2010; Griffith, 2009; Henderson, Brown, Pancer, \& Ellis-Hale, 2007).

Hypothesis 1: Demographic variables such as age, gender, race, and level of education will affect youth participation in UA.

\subsection{The Theory of Planned Behaviour}

According to Warburton et al. (2001) two major theoretical approaches have been applied to predict determinants of volunteerism namely; Ajzen's 1991 theory of planned behaviour and Clary \& Snyder's 1999 functional approach. The first most important theoretical approach to understanding volunteer participation is the theory of planned behaviour (Greenslade \& White, 2005). Similarly, Hauser, Koontz, \& Bruskotter (2012) reported that the Theory of Planned Behaviour might serve as a useful starting point to understand volunteer participation.

This theory has been successfully used to predict volunteer behaviour (Greenslade \& White, 2005). The theory explains that people make decisions logically using existing information. The model hypothesizes that the antecedents of behaviour are a sequence of cognitions (Fishbein \& Ajzen, 1975). Ajzen, (1991) supposed that the immediate antecedent of behaviour is the person's intention to accomplish it. Intentions are function of three independent determinants namely; attitude, subjective norm and perceived behavioural control. The person's attitude refers to the degree to which a person has a positive or negative evaluation of the behaviour (Vermeir \& Verbeke, 2008). The subjective norm reveals perceived social pressure to accomplish or not accomplish the behaviour (Ajzen, 1991). The perceived behavioural control reflects the extent to which the person perceives the behaviour to be under volitional control. It indicates whether people easily participate or whether participation is difficult. Normally it reflects past experience as well as expected problems. According to Vermeir \& Verbeke, (2008) when people feel that they are lacking the resources or opportunities to accomplish a behaviour, they are unlikely to develop intentions to perform the behaviour. Sparks, Guthrie, \& Shepherd (1997) have pointed out that perceived behavioural control reflects both inner control factors such as self-efficacy and external perceived difficulty factors such as perceived obstacles.

Hypothesis 2: Considering the planned behaviour model, intention to participate in UA will be influenced by attitudes, subjective norms, and perceived behavioural control.

\subsection{The Theory of Volunteering Functions}

The second theoretical approach to understanding volunteer participation is the theory of Volunteering Functions. Many scholars practise motivational theories to explain volunteering. The Volunteer Function Inventory (VFI) identifies a set of motives that volunteer effort can help satisfy. The functional approach is a multi-motivational perspective. This approach helps to reveal the fundamental motivations of volunteers. According to this theory, for an individual, performing a volunteer activity may fulfil more than one motive (Houle, Sagarin, \& Kaplan, 2005).

Clary \& Snyder (1999) found that volunteerism depends on matching a person's motivation with the volunteer situation. Understanding volunteer motivation would be helpful to both the programme organizer and volunteers as it would enable programme organizers to make efforts towards increasing volunteer participation. This is also important in recruiting and sustaining volunteers. According to Clary \& Snyder (1999) understanding volunteer motivations is essential to develop volunteer retention strategies. Similarly, Auld \& Cuskelly (2001) and Farrell, Johnston, \& Twynam (1998) reported that prior to volunteer recruitment we need to understand the motivation of volunteers (Cnaan \& Goldberg-Glen, 1991).

Based on the functional analysis of volunteerism, people may have different motivations even though involved in the same acts. Clary et al. (1998) listed six functions of volunteerism. The first function is the values function. The values function refers to concerns for the benefit of others, and contributions to society. The understanding function is the second one in which volunteerism provides an opportunity for understanding and learning. Gidron (1978) confirmed the validity of this function, finding that young volunteers such as high school and college students view their volunteer work as learning experience. The third function is the career function. Volunteerism 
might help to enhance one's career. In line with this, Beale (1984) recommended encouraging students to volunteer as a "stepping stone" to employment. A fourth function is the social function in which an individual volunteers due to norms, social pressures and to conform with others in his or her reference group. A fifth function that might be served by volunteerism is the protective function whereby a person volunteers to lessen feelings of guilt about being more fortunate than others, or to escape from one's own problems. Schwartz (1970) showed that individuals had a greater level of commitment to volunteer when the level of personal responsibility for others was high. This function is the enhancement function in which volunteerism serves to enhance self-esteem and self-confidence.

Hypothesis 3: In relation to the functional approach, we expected that volunteer functions such as value, social pressure, learning experience, enhanced self-esteem, reduced feeling of guilt and job opportunities would predict youth voluntary participation in UA.

\subsection{Predictors of Youth Participation in Voluntary Programmes}

The study of why students choose to participate in agricultural activities has a long history (Rayfield, Compton, Doerfert, Fraze, \& Akers, 2008). Youth might be motivated to participate in a programme for many different reasons. Studies have shown factors such as fun and enjoyment, learning purpose, need for relatedness and belonging, and future effectiveness, (Eccles \& Gootman, 2002; Ferrer-Caja \& Weiss, 2000; Fredricks et al., 2002). Weiss, Little, \& Bouffard (2005) identified factors such as personal characteristics, perceptions of family or friends about the activity, school/university characteristics, and neighbourhood characteristics for youth participation in after-school programmes.

Marshall, Herring, and Briers (1992) found that Texas (USA) students joined FFA (Future Farmers of America) because it enhanced their identity as a person. Talbert \& Balschweid (2004) reported that students who joined FFA programmes had parents or siblings involved in agricultural education or activities related to agriculture such as living on a farm. FFA members believed that the agriculture teacher had an influence on their decision to enrol and participate in agricultural activities. In another study conducted by Rayfield et al. (2008) there were a few factors that influenced youth participation in FFA; high school Grade Point Average (GPA), participation in on-campus activities, agreement with the statement "Leadership activities have made me a more confident person," and which school year the students belong to. According to the Harvard Family Research Project (2004), older youth may participate in community programmes only when they are offered a flexible schedule for particular days or times.

Youths report a bigger probability of getting involved if their participation is valued by parents or teachers (Camino, 2000; Fogel, 2004; Jarrett, Sullivan, \& Watkins, 2005). The receptivity of authority figures can play a central role in youth efficacy, their engagement, and their continued involvement in the community. Often, youth have not been noticed as important contributors to society, mostly due to misconceptions about their age and developmental capacity. The results of a study conducted by Roberts et al. (2009) support that factors such as meaningful engagement, peer opinion, personal aspirations, high expectations, and recognition positively influence students to participate in agricultural education activities and FFA membership. In line with this finding, the views and opinions of older adults can significantly influence younger adults and youth participation in society. Zeldin (2002) reported that many adults believe that youth have the potential to contribute to their communities. According to Camino (2000) this notion opens the door to long-term youth involvement.

Sutphin \& Newsom-Stewart (1995) report several predictor factors that influence students to participate in an educational programme such as: beliefs and attitudes, activities, experiences, and youth development opportunities. Similarly, theories of cognitive and social psychology (Ausubel, 1977; Bandura, 1986; Novak, 1977) support the link between student attitudes and beliefs, and participation in agricultural programmes. Ferrari \& Turner (2006) studied why adolescents joined and continued to participate in a programme. Their findings revealed that youth felt a sense of belonging and safety, they received the academic support they needed, and they had fun. They had also developed relationships with adults with fulfilled meaningful roles. Parents' religiosity is partly responsible for how their children become engaged in society. According to Caputo (2009), American adolescents whose parents are volunteers are more likely to become volunteers in social activism, whereas youths whose parents are religious are more likely to be directed away from social engagement into volunteering exclusively.

\subsection{Barriers to Youth Voluntary Participation}

Previous research identified numerous general barriers to students' participation in a programme. These barriers include lack of transportation (Dynarski et al., 2003; Martin \& Kitchell, 2014), family responsibility (Borden, Perkins, Villarruel, \& Stone, 2005; Grossman et al., 2002; Lauver, 2002; Sanderson \& Richards, 2010), lack of 
parental encouragement (Sanderson \& Richards, 2010; Simpkins, Davis-Kean, \& Eccles, 2005), and concern for students' safety (Sanderson \& Richards, 2010), the need to relax with friends and family after school or having no interest in the programmes (Halpern, 2000; Weisman \& Gottfredson, 2001), the need to work after school (Lauver, Little, \& Weiss, 2004), and feeling unsafe when travelling to and from after-school activities (Grossman et al., 2002; Lauver, 2002). These barriers show influences related to family, friends, and community.

Other factors such as lack of time (Sherrod, Flanagan, \& Youniss, 2002), and not being sure of the benefits of their contributions (Israel, Coleman, \& Ilvento, 1993) can limit youth participation. Scales \& Leffert, (1999) reported four barriers that limit youth participation namely; lack of interesting programmes, lack of knowledge about programmes, cost, and transportation. Researchers identified that a lack of role models in the FFA (LaVergne, Larke, Elbert, \& Jones, 2011) could also form barriers to urban students' FFA participation. Furthermore, lack of diversity among agriculture teachers and characteristics of the agriculture programme have also been recognized as barriers to urban students' participation in after school programmes. Obstacles such as not being taken seriously, not being asked, and not being assigned with an identifiable role are reported in the research literature as significant obstacles that discourage youth from participating in community activities.

Other obstacles to youth participation in communty activities such as lack of communication and awareness of opportunities and youth fears of speaking out are identified by Felix (2003). Research conducted by Thompson (1998) and presented by Homan, Dick, \& Hedrick (2008), provided three reasons why individuals did not enrol in programmes: too busy, having other more important activities, and not enough time. A study was conducted by Martine and Kitchel (2014) to investigate barriers to participation in FFA among urban high school agriculture students in an urban school district. Results revealed that barriers such as lack of transportation and need to care for family members echoed the findings from other educational studies (Sanderson \& Richards, 2010; Simpkins, Davis-Kean, et al., 2005).

The involvement of youth in the UA programme has many benefits that bring about positive character development in general. Volunteerism gives youths valuable experiences that can be used to search for job opportunities. Despite the barriers in terms of some adults' negative attitudes towards youth, lowered sense of safety and inadequate provision of the support it merits by political bodies, volunteerism is gaining increased recognition as a platform for making a positive contribution towards the improvement of society. Based on two related theories and the review of the literature, a conceptual framework was formed for this study.

Hypothesis 4: Barriers to participation such as lack of time, lack of interest, transport and so on, will affect youth participation in UA. 


\section{Attitude towards UA}

2. Subjective norms:

2.1. Stimulation by importance others such as friends and family, teachers, lecturers, mentors, attach to UA

2.2. Being asked to volunteer

2.3. Sense of belonging to university and community

3. Perceived behavioural control/ Perceived barriers such as:

3.1. Lack of time

3.2. Lack of transportation

3.3. Family responsibility

3.4. Lack of knowlege of programme

3.5. Feeling unsafe

3.6. Not being taken seriously

3.7. Self-efficacy

3.8. Availability of resources

Motivational factors:

1-Added value

2-Social pressure

3-Opportunity for learning experience

4-Enhance self-confidence

5-Reduce feelings of guilt

6-Create job opportunities

\section{Demographic variables:}

1-Age

2-Gender

3-Race

4-Level of education

5-Field of study

6-Family history in agriculture

7 -Residence of city or rural area

8-Family income

9-Participation in on-campus activities

10-GPA

\section{Conclusions and Recommendations}

Agricultural is an important sector for development. UA is becoming increasingly important for Malaysia. 
Encouraging voluntary participation in urban agriculture is a new movement. Involving young people in this national programme will empower them with the notion that they can translate national goals into tangible reality. Integrating students to participate particularly in UA is a long-term investment, as this generation of young people will witness the consequences of their voluntary choice. Recognizing young students' meaningful participation will increase their likelihood of a successful transition into responsible citizens and will increase the probability of success of the UA development programme in the country.

In this paper, potentially appropriate theories have been proposed. The review paper highlighted factors predicting participation of young students in a voluntary programme. The paper elaborated what scholars have published on the factors influencing youth to participate in a programme. The review offers numerous psychosocial, motivational, and individual determinants that can be used to predict voluntary participation. This study also offers several barriers that students might encounter to participating in a voluntary programme. Identified obstacles that inhibit youth participation provide important information for programme planners to remove physical and psychological barriers. In order to encourage youth participation in UA programmes, strategies should tailor motivational, psychosocial, and individual factors. Strategies should be adapted in order to inspire young students to participate in UA dynamically and continuously. Overall, this work suggests that great care should be taken when requiring young people to perform an activity of volunteering. One of the implications of the functional approach would be for the recruitment, placement, and retention of volunteers. It is important to consider the motivation of volunteers when recruiting or selecting volunteers. Furthermore, volunteer behaviours do not depend solely on the person or on the situation itself, but rather depend on the interaction between person and situational opportunities. Therefore both personal and situational factors should be taken into consideration.

In the context of Malaysian youth, involving in agricultural related volunteer work has several cultural connotations. To the young Malaysians, agriculture is associated with uncertainties, unglamorous, and dirty. Thus, in relation to the planned behavioral model (sub variables influencing participation include attitudes and subjective norms) and functional approach (volunteer functions sub variable iclude value, social pressure, enhance self -esteem, reduce feeling of guilt, and job opportunity), the items to be developed in the research instrument should be in line with Malaysia scenario as to ensure prediction capability of the variables is contextual. To this end it recommended that the following elements to be considered as guides in developing the items: Inculcating positive attitude toward agriculture related venture; planned for long term involvement through quality youth programs/organizations; eliminating negative perceptions of concerned adults; and doing volunteer work in an environment of interdependent between youth and concerned adults.

Practical recommendations are provided here for administrators of the voluntary programme who seek to increase the number of volunteers and to improve their human resource management.

- It is recommended that UPM inspires students to participate in the UA programme as part of their curriculum of studies and even as a condition of graduation. A mandatory volunteerism programme in which university students are required to perform at least 30-40 hours of community service over the course of a semester will increase the probabilities that students will have higher intentions to volunteer in future. Colleges and faculties should also increase the number of courses that require service learning.

-Effort should be devoted to recruiting and training volunteers to extend the effectiveness of the young volunteers. This indicates additional training for youth volunteers.

-As extension education is being used as the main service delivery instrument by students, efforts should be made to strengthen the field of extension education in UPM.

-Since UA is becoming important in Malaysia, students' awareness concerning the UA programme must be taken into account. UPM should further promote the programme and voluntary participation in the programme.

-Faculties and research institutes in UPM could support the programme by carrying out research to identify which factors most influence Malaysian young students to voluntarily participate in the programme. It is also recommended that an investment is made in further research targetting youth from various backgrounds.

\section{Future Research}

Future research may take two directions: (a) to study the interventions and activities of successful youth voluntary participation, and (b) to pursue research that predicts Malaysian youth voluntary participation focusing exclusively on urban agriculture.

Research is needed to explore what are the barriers to UPM students' participation in the voluntary UA programme and how to overcome these barriers. These explanations could help stakeholders design a 
programme that appeals to more students.

Further research is needed to validate identified factors in the literature that influence Malaysian urban students. Research should also be conducted to determine if certain variables are more influential than others.

Researchers interested in the current study could examine the moderating and mediating effects of demographic factors. Additional research is also needed to examine UPM volunteers' motivation to particiapte in UA. A better understanding of volunteer motivation would be helpful to both the programme organizers and volunteers as it would enable programme organizers to direct efforts towards enhancing volunteer participation.

\section{References}

Ajzen, I. (1991). The theory of planned behavior. Organizational Behavior and Human Decision Processes, 50(2), 179-211. http://dx.doi.org/10.1016/0749-5978(91)90020-T

Auld, C., \& Cuskelly, G. (2001). Behavioural characteristics of volunteers: implications for community sport and recreation organisations. Australian Parks and Leisure, 4(2), 29-37.

Ausubel, D. P. (1977). The facilitation of meaningful verbal learning in the classroom 1. Educational Psychologist, 12(2), 162-178. http://dx.doi.org/10.1080/00461527709529171

Bandura, A. (1986). Social learning theory. Learning Theories and Models Summaries (in Plain English). Retrieved from http://www.learning-theories.com/social-learning-theory-bandura.html

Beale, A. V. (1984). Exploring careers through volunteerism. School Counselor, 32(1), 68-71.

Borden, L. M., Perkins, D. F., Villarruel, F. A., \& Stone, M. R. (2005). To participate or not to participate: That is the question. New Directions for Youth Development, 2005(105), 33-49. http://dx.doi.org/10.1002/yd.106

Bowman, N., Brandenberger, J., Lapsley, D., Hill, P., \& Quaranto, J. (2010). Serving in college, flourishing in adulthood: Does community engagement during the college years predict adult well-being? Applied Psychology: Health and Well-Being, 2(1), 14-34. http://dx.doi.org/10.1111/j.1758-0854.2009.01020.x

Brand, J. E. (2010). Civic returns to Higher Education: A note on heterogeneous effects. Social Forces, 89(2), 417-433. http://dx.doi.org/10.1353/sof.2010.0095

Camino, L. A. (2000). Youth-adult partnerships: Entering new territory in community work and research. Applied Developmental Science, 4(sup1), 11-20. http://dx.doi.org/10.1207/S1532480XADS04Suppl_2

Caputo, R. K. (2009). Religious capital and intergenerational transmission of volunteering as correlates of civic engagement. Nonprofit and Voluntary Sector Quarterly, 38(6), 983-1002. http://dx.doi.org/10.1177/0899764008323990

Clary, E. G., \& Snyder, M. (1999). The motivations to volunteer theoretical and practical considerations. Current Directions in Psychological Science, 8(5), 156-159. http://dx.doi.org/10.1111/1467-8721.00037

Clary, E. G., Snyder, M., Ridge, R. D., Copeland, J., Stukas, A. A., Haugen, J. ... Miene, P. (1998). Understanding and assessing the motivations of volunteers: A functional approach. Journal of Personality and Social Psychology, 74(6), 1516-1530. http://dx.doi.org/10.1037/0022-3514.74.6.1516

Cnaan, R. A., \& Goldberg-Glen, R. S. (1991). Measuring motivation to volunteer in human services. The Journal of Applied Behavioral Science, 27(3), 269-284. http://dx.doi.org/10.1177/0021886391273003

Duflot, L. (2012). Urbanization Policy in Malaysia and its Impacts. Graphite Publications. Retrieved from http://graphitepublications.com/urbanization-policy-in-malaysia-and-its-impacts/

Dynarski, M., Moore, M., Mullens, J., Gleason, P., James-Burdumy, S., Rosenberg, L. ... Levy, D. (2003). When Schools Stay Open Late: The National Evaluation of the 21st Century Community Learning Centers Program. First Year Findings (Mathematica Policy Research Reports No. 3402). Mathematica Policy Research. Retrieved from http://ideas.repec.org/p/mpr/mprres/3402.html

Eccles, J., \& Gootman, J. A. (2002). Community Programs to Promote Youth Development. National Academies Press.

Einolf, C. J. (2011). Gender differences in the correlates of volunteering and charitable giving. Nonprofit and Voluntary Sector Quarterly, 40(6), 1092-1112. http://dx.doi.org/10.1177/0899764010385949

Farrell, J. M., Johnston, M. E., \& Twynam, G. D. (1998). Volunteer motivation, satisfaction, and management at an elite sporting competition. Journal of Sport Management, 12(4), 288-300.

Ferrari, T. M., \& Turner, C. L. (2006). An exploratory study of adolescents' motivations for joining and 
continued participation in a 4-H afterschool program. Journal of Extension, 44(4), 1-12. Retrieved from http://www.joe.org/joe/2006august/rb3p.shtml

Ferrer, C. E., \& Weiss, M. R. (2000). Predictors of intrinsic motivation among adolescent students in physical education. Research Quarterly for Exercise and Sport, 71(3), 267-279. http://dx.doi.org/10.1080/02701367.2000.10608907

Fishbein, M., \& Ajzen, I. (1975). Belief, attitude, intention and behavior: An introduction to theory and research. Retrieved from http://trid.trb.org/view.aspx?id=1150648

Fogel, S. (2004). Risks and opportunities for success: Perceptions of urban youths in a distressed community and lessons for adults. Families in Society: The Journal of Contemporary Social Services, 85(3), 335-344. http://dx.doi.org/10.1606/1044-3894.1494

Foster, B. J. (2008). Do Race, Ethnicity, Citizenship and Socio-economic Status Determine Civic-Engagement? CIRCLE Working Paper \#62. Center for Information and Research on Civic Learning and Engagement (CIRCLE).

Fredricks, J. A., Alfeld, L. C. J., Hruda, L. Z., Eccles, J. S., Patrick, H., \& Ryan, A. M. (2002). A qualitative exploration of adolescents' commitment to athletics and the arts. Journal of Adolescent Research, 17(1), 68-97. http://dx.doi.org/10.1177/0743558402171004

Gesthuizen, M., \& Scheepers, P. (2010). Educational differences in volunteering in cross-national perspective: Individual and contextual explanations. Nonprofit and Voluntary Sector Quarterly, 0899764010394203. http://dx.doi.org/10.1177/0899764010394203

Gesthuizen, M., Meer, T. V., \& Scheepers, P. (2008). Education and dimensions of social capital: Do educational effects differ due to educational expansion and social security expenditure? European Sociological Review, 24(5), 617-632. http://dx.doi.org/10.1093/esr/jen021

Gidron, B. (1978). Volunteer work and its rewards. Volunteer Administration, 11(3), 18-32.

Greenslade, J. H., \& White, K. M. (2005). The prediction of above-average participation in volunteerism: A test of the theory of planned behavior and the volunteers functions inventory in older Australian adults. The Journal of Social Psychology, 145(2), 155-172. Retrieved from http://www.tandfonline.com/doi/abs/10.3200/SOCP.145.2.155-172

Griffith, J. (2009). Community service among a panel of beginning college students: Its prevalence and relationship to having been required and to supporting "capital." Nonprofit and Voluntary Sector Quarterly. http://dx.doi.org/10.1177/0899764009338218

Grossman, J. B., Price, M. L., Fellerath, V., Jucovy, L. Z., Kotloff, L. J., Raley, R., \& Walker, K. E. (2002). Multiple Choices after School: Findings from the Extended-Service Schools Initiative. Retrieved from http://eric.ed.gov/?id=ED468056

Halpern, R. (2000). The promise of after-school programs for low-income children. Early Childhood Research Quarterly, 15(2), 185-214. http://dx.doi.org/10.1016/S0885-2006(00)00056-9

Harvard Family Research Project, H. F. R. P. (2004). Harvard Family Research Project. Retrieved July 18, 2014 , Retrieved from http://www.hfrp.org/hfrp-news/news-announcements/(year)/2004

Haski-Leventhal, D., \& Cnaan, R. A. (2009). Group processes and volunteering: Using groups to enhance volunteerism. Administration in Social Work, 33(1), 61-80. http://dx.doi.org/10.1080/03643100802508635

Hauser, B. K., Koontz, T. M., \& Bruskotter, J. T. (2012). Volunteer participation in collaborative watershed partnerships: insights from the Theory of Planned Behaviour. Journal of Environmental Planning and Management, 55(1), 77-94. http://dx.doi.org/10.1080/09640568.2011.581535

Henderson, A., Brown, S. D., Pancer, S. M., \& Ellis, H. K. (2007). Mandated community service in high school and subsequent civic engagement: The case of the "double cohort" in Ontario, Canada. Journal of Youth and Adolescence, 36(7), 849-860. http://dx.doi.org/10.1007/s10964-007-9207-1

Homan, J., Dick, J., \& Hedrick, J. (2008). Retrieved July 22, 2014, Retrieved from http://ohioline.osu.edu/4h-fact/pdf/0029.pdf

Houle, B. J., Sagarin, B. J., \& Kaplan, M. F. (2005). A functional approach to volunteerism: Do volunteer motives predict task preference? Basic and Applied Social Psychology, 27(4), 337-344. http://dx.doi.org/10.1207/s15324834basp2704_6

Huang, J., Maassen van den Brink, H., \& Groot, W. (2009). A meta-analysis of the effect of education on social 
capital. Economics of Education $\quad$ Review, 28(4), $454-464$. http://dx.doi.org/10.1016/j.econedurev.2008.03.004

Israel, G. D., Coleman, D. L., \& Ilvento, T. W. (1993). Student involvement in community needs assessment. Community Development Society Journal, 24(2), 249-269. http://dx.doi.org/10.1080/15575339309489911

Jarrett, R. L., Sullivan, P. J., \& Watkins, N. D. (2005). Developing social capital through participation in organized youth programs: Qualitative insights from three programs. Journal of Community Psychology, 33(1), 41-55. http://dx.doi.org/10.1002/jcop.20038

Koehler, B., \& Koontz, T. M. (2008). Citizen participation in collaborative watershed partnerships. Environmental Management, 41(2), 143-154. http://dx.doi.org/10.1007/s00267-007-9040-z

Laurence, J. (2009). The effect of ethnic diversity and community disadvantage on social cohesion: A multi-level analysis of social capital and interethnic relations in UK communities. European Sociological Review, jcp057. http://dx.doi.org/10.1093/esr/jcp057

Lauver, S. C. (2002). Assessing the benefits of an after-school program for urban youth: An impact and process evaluation. Dissertations Available from ProQuest, 1-240. Retrieved from http://repository.upenn.edu/dissertations/AAI3043903

Lauver, S., Little, P., \& Weiss, H. (2004). Moving Beyond the Barriers: Attracting and Sustaining Youth Participation in Out-of-School Time Programs / Browse Our Publications / Publications \& Resources / HFRP - Harvard Family Research Project. Retrieved July 22, 2014, from http://www.hfrp.org/publications-resources/browse-our-publications/moving-beyond-the-barriers-attractingand-sustaining-youth-participation-in-out-of-school-time programs

LaVergne, D. D., Larke, A., Elbert, C. D., \& Jones, W. A. (2011). The benefits and barriers toward diversity inclusion regarding agricultural science teachers in Texas secondary agricultural education programs. Journal of Agricultural Education, 52(2), 140-150.

Lee, Y., \& Brudney, J. L. (2009). Rational volunteering: a benefit-cost approach. International Journal of Sociology and Social Policy, 29(9/10), 512-530. http://dx.doi.org/10.1108/01443330910986298

Martin, M., \& Kitchell, T. (2014). Barriers to participation in the national FFA organization according to urban agriculture students. Journal of Agricultural Education, 55(1), 120-133. http://dx.doi.org/10.5032/jae.2014.01120

Martinez, T. A., \& McMullin, S. L. (2004). Factors affecting decisions to volunteer in nongovernmental organizations. Environment and Behavior, 36(1), 112-126. http://dx.doi.org/10.1177/0013916503256642

McFarland, D. A., \& Thomas, R. J. (2006). Bowling young: How youth voluntary associations influence adult political participation. American Sociological Review, 71(3), 401-425. http://dx.doi.org/10.1177/000312240607100303

Novak, J. D. (1977). A Theory of Education. Cornell University Press.

Omoto, A. M., Snyder, M., \& Hackett, J. D. (2010). Personality and motivational antecedents of activism and $\begin{array}{lllll}\text { civic } \quad \text { Journal } & \text { of } & \text { Personality, } & \text { 78(6), }\end{array}$ http://dx.doi.org/10.1111/j.1467-6494.2010.00667.x

Pho, Y. H. (2008). The value of volunteer labor and the factors influencing participation: Evidence for the United States from 2002 through 2005. Review of Income and Wealth, 54(2), $220-236$. http://dx.doi.org/10.1111/j.1475-4991.2008.00271.x

Rayfield, J., Compton, K., Doerfert, D., Fraze, S., \& Akers, C. (2008). Factors that influence the decision to participate in youth organizations in rural high schools in three states. Journal of Agricultural Education, 49(4), 83-95.

Roberts, T. G., Hall, J. L., Briers, G. E., Gill, E., Shinn, G. C., Larke, A., \& Jaure, P. (2009). Engaging Hispanic students in agricultural education and the FFA: A 3-year case study. Journal of Agricultural Education, 50(3), 69-80.

Sanderson, R. C., \& Richards, M. H. (2010). The after-school needs and resources of a low-income urban community: Surveying youth and parents for community change. American Journal of Community Psychology, 45(3-4), 430-440. http://dx.doi.org/10.1007/s10464-010-9309-x

Scales, P., \& Leffert, N. (1999). Developmental Assets: A Synthesis of the Scientific Research on Adolescent Development. Barnes \& Noble. Retrieved July 22, 2014, Retrieved from http://www.barnesandnoble.com/w/developmental-assets-peter-c-scales/1111915424 
Schwartz, B. (1970). Notes on the sociology of sleep. Sociological Quarterly, 11(4), 485-499. http://dx.doi.org/10.1111/j.1533-8525.1970.tb01320.x

Sherrod, L. R., Flanagan, C., \& Youniss, J. (2002). Dimensions of citizenship and opportunities for youth development: The what, why, when, where, and who of citizenship development. Applied Developmental Science, 6(4), 264-272. http://dx.doi.org/10.1207/S1532480XADS0604_14

Simpkins, S. D., Davis-Kean, P. E., \& Eccles, J. S. (2005). Parents\&\#039; socializing behavior and children\&\#039;s participation in math, science, and computer out-of-School activities. Applied Developmental Science, 9(1), 14-30. http://dx.doi.org/10.1207/s1532480xads0901_3

Simpkins, S. D., Ripke, M., Huston, A. C., \& Eccles, J. S. (2005). Predicting participation and outcomes in out-of-school activities: Similarities and differences across social ecologies. New Directions for Youth Development, 2005(105), 51-69. http://dx.doi.org/10.1002/yd.107

Smith, D. H. (1994). Determinants of voluntary association participation and volunteering: A literature review. Nonprofit and Voluntary Sector Quarterly, 23(3), 243-263. http://dx.doi.org/10.1177/089976409402300305

Snyder, M., \& Omoto, A. M. (2008). Volunteerism: Social issues perspectives and social policy implications. Social Issues and Policy Review, 2(1), 1-36. http://dx.doi.org/10.1111/j.1751-2409.2008.00009.x

Sparks, P., Guthrie, C. A., \& Shepherd, R. (1997). The dimensional structure of the perceived behavioral control

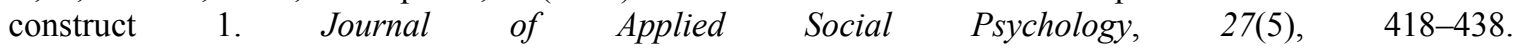
http://dx.doi.org/10.1111/j.1559-1816.1997.tb00639.x

Sutphin, H. D., \& Newsom-Stewart, M. (1995). Students' rationale for selection of agriculturally related courses in high school by gender and ethnicity, 32(2), 54-61. Retrieved from http://pubs.aged.tamu.edu/jae/pdf/vol36/36-02-54.pdf

Talbert, B. A., \& Balschweid, M. A. (2004). Engaging students in the agricultural education model: Factors affecting student participation in the national FFA organization. Journal of Agricultural Education, 1(45), 29-41. Retrieved from http://bern.library.nenu.edu.cn/upload/soft/0-a/45-01-029.pdf

Verduzco, G. (2010). Graphic "acts of solidarity in Mexico" (Analysis of the national survey on solidarity and volunteer action). In J. Butcher (Ed.), Mexican Solidarity (pp. 33-69). Springer New York. Retrieved from http://link.springer.com/chapter/10.1007/978-1-4419-1078-3_2

Vermeir, I., \& Verbeke, W. (2008). Sustainable food consumption among young adults in Belgium: Theory of planned behaviour and the role of confidence and values. Ecological Economics, 64(3), 542-553. http://dx.doi.org/10.1016/j.ecolecon.2007.03.007

Warburton, J., Terry, D. J., Rosenman, L. S., \& Shapiro, M. (2001). Differences between older volunteers and nonvolunteers attitudinal, normative, and control beliefs. Research on Aging, 23(5), 586-605. http://dx.doi.org/10.1177/0164027501235004

Weisman, S. A., \& Gottfredson, D. C. (2001). Attrition from after school programs: characteristics of students who drop out. Prevention Science: The Official Journal of the Society for Prevention Research, 2(3), 201-205.

Weiss, H. B., Little, P. M. D., \& Bouffard, S. M. (2005). More than just being there: Balancing the participation equation. New Directions for Youth Development, 2005(105), 15-31. http://dx.doi.org/10.1002/yd.105

Wilson, J. (2012). Volunteerism research a review essay. Nonprofit and Voluntary Sector Quarterly, 41(2), 176-212. http://dx.doi.org/10.1177/0899764011434558

Wilson, J., \& Musick, M. (1999). The effects of volunteering on the volunteer. Law and Contemporary Problems, 62(4), 141-168. http://dx.doi.org/10.2307/1192270

Zeldin, S. (2002). Sense of community and positive adult beliefs toward adolescents and youth policy in urban Neighborhood and small cities. Journal of Youth and Adolescence, 31(5), 331-342. http://dx.doi.org/10.1023/A:1015624507644

\section{Copyrights}

Copyright for this article is retained by the author(s), with first publication rights granted to the journal.

This is an open-access article distributed under the terms and conditions of the Creative Commons Attribution license (http://creativecommons.org/licenses/by/3.0/). 